\title{
76
}

Rupantaran : A Multidisciplinary Journal

Vol. III : 76-83, March, 2020

ISSN : 2091-0061

Research Management Cell (RMC)

Dhankuta Multiple Campus, Dhankuta

Tribhuvan University, Nepal

\section{The Question of Transformation in the English Language Education Classroom}

\author{
Netra Prasad Sharma ${ }^{1}$ \\ Email: tu.netrasharma@gmail.com
}

\begin{abstract}
Have we transformed ourselves? The question that frequently arises in the discourse pertaining to the reintroduction of the semester system in the different faculties of Tribhuvan University has taken the shape of this paper that attempts to probe into the demeanour of both teachers and students in the English language education classrooms in the Kathmandu valley. The data collected through a brief survey of student opinions and informal discussion with concerned teachers portray the classroom scenarios that are difficult to differentiate from the ones that usually characterize the classrooms in the "annual system" of teaching and testing. This portrayal suggests the future course of action on the part of teachers and students both.
\end{abstract}

Key Words: Transformation, Semester system, Demeanour of students, Teacher role, Learning-centred

\section{Introduction}

The reintroduction of the semester system in the different faculties of Tribhuvan University (TU) in 2014 has completed its first cycle and the reactions from the different quarters of stakeholders, particularly students and teachers, have surfaced vehemently and mostly in a counter-note, at times some voices in a positive note though. In this air of discourse taking place about the pros and cons of the semester system, a big question that is raised among the concerned is "How far have we been transformed along with the reintroduction of the semester system?" - the very nub of this paper. Although this question might seem to be addressed by the teachers and the students who are involved directly in the teaching-learning activities, it is no less relevant concerning the other stakeholders such as different administrative bodies of TU - the bodies that are responsible and accountable for creating a conducive environment, as

1. Mr. Shrama is a lecturer of English education at Tribhuvan University, Mahendra Ratna Campus, Kathmandu. 
envisaged in the semester system, where teachers and students can work efficiently for academic achievements. Nonetheless, this paper leaves this important facet of the semester system (i.e. administrative one) aside and concentrates itself on teachinglearning activities and, therefore, the demeanour of students and teachers.

\section{Expectations from teachers and students}

"Learning is driven by what teachers and pupils do in classrooms" (Black \& Wiliam, 1998, p. 1). The roles of the teacher and the student largely depend on what approach to language and language learning is held during the teaching-learning process (Richards \& Rodgers, 2002). Thus, the teacher roles might range from a rather conventional role of an authority in the classroom, director and source of knowledge, to that, in relatively more modernist approaches, of a needs analyst, counselor, facilitator, guide, colleague and the like. So is the case of the student, even though the role is, to a great extent,

Semester practices assume a vibrant relationship between students and teachers in terms of their communication regarding teaching and learning - in effect, a pivotal construct that eases all the other facets of the semester system. Singh and Kumar (2016) prop the fact when they assert that "there will be a continuous engagement between students and teachers which will result in a more focused class interaction" (p. 89). The teacher is expected to weigh the different aspects of his/her students and to conduct teaching-learning activities accordingly. Therefore, the teacher's activities become learning-centred rather than teaching-centred (Pathak \& Rahman 2013), and, therefore, the teacher's efforts centre around what students are required to master and how they do so. In this sense, then, different roles are assumed on the part of the teacher - the roles being that of a needs analyst, facilitator, co-communicator, group member, assessor, and the like. Nevertheless, the relationship between the teacher and the student in the annual system is naturally weaker as compared to that in the semester system. The difference between the annual and the semester systems in terms of teacher role is not, in fact, that of degree but is a shift in the teacher's paradigm. It is also probably therefore that Pabla (2014, p. 173) opines that the rationale underneath the semester system is "to impart enhanced value".

The teacher working in the semester system is expected to assess his/her students frequently employing not only the formal assessments provisioned in a course of study but also the informal ones so that learning goals can be furthered - one of the benefits of tests and assessments being the motivation of students in what is assessed. It is possible because of the "freedom and flexibility" (Shoukat and Muhammad, 2015) allowed to the teachers in the semester system in the process of teaching and assessing students. 
"Accessibility of teachers "(Pabla, 2014) on the part of students is another important condition that creates a favourable atmosphere for them to better pursue their learning goals in the semester system. In addition to the opportunities for students to consult their teachers for solving problems, they should also be informed of different assessment criteria in advance and given a chance individually to discuss with their teachers the strengths and weaknesses of their performances and the resulting scores.

As to the role of students in the semester system, it is highly imperative on the part of students to comprehend that "learning of student [sic.] is more important as compared to their position, marks and G. P. A." (Aslam, Younis, Sheik, Maher \& Abbasi, 2012, p. 163). Students "cannot focus on anything else apart from the curriculum but this is not the case with annual system" (Yousaf \& Hashim, 2012, p. 54). "Regularity" (Pabla, 2014) on the part of students is, therefore, mandatory as it is so in case of teachers as well. Similarly, Singh and Kumar (2016) focus on the "regular study habit of students". Thus, in the semester system one can assume without difficulty that students are well-motivated in doing what they are supposed to and that they value learning more than scores or grades and also that they avoid any sort of malpractice that would take place if they valued scores rather than learning.

Duvie and Eluwa (2016) conceive examination malpractice as "any irregular action taken by examinees, examiners or any other persons associated with an examination whether before, during and after, that gives undue advantage to certain individuals" (p. 48). This phenomenon is common across the world, nature and degree may vary depending on a given context though. There might be different factors behind students' involvement in examination malpractice. For instance, Anzene (2014) discusses the factors such as the values of a society, emphasis on certificate rather than learning, inadequate teaching and learning, lack of confidence in students, low moral grounds, focus on success without following the means to get to the success, and so on. The measures that could be taken for curbing students' malpractices might include many and "continuous assessment" is one of such solutions (Duvie \& Eluwa, 2016; Olubukola \& Bankole, 2015). In addition to continuous assessment, in-depth learning, regularity of both teachers and students, communication between teachers and students, and the like are the other characteristic features of the semester system. What follows from this all is that, at least, one can expect the significantly reduced degree of student malpractice (if not its nonexistence) in semester examinations. This assertion does never, however, mean that there is more of such malpractice in the annual system. The assertion is only the logical conclusion of the discussion on the characteristic features of the semester system.

\section{Purpose of the study}

This study intended to explore the classroom practices in terms of the demeanour of teachers and students at the Master's level in English language education. 


\section{Methods and Materials}

A brief survey of the opinions of the students studying in the third and the fourth semesters at the Master's level in English language education and the informal discussions with the three teachers teaching different courses of study to the same groups of students were conducted in order to gather the data for this study. The opinions of the students were collected through a questionnaire administered to seventy-nine students, whereas the data from the informal discussions were recorded by note-taking and the reconstruction of the major points of the discussions within a few post-discussion hours. The data obtained through informal discussions were used only to substantiate the discussion of the data obtained through the questionnaire.

\section{Results and Discussion}

The data obtained through the questionnaire administered to the students are presented in Table 1. Note that, for conciseness, the constructs in the table have been derived from the full statements placed in the questionnaire.

As a good majority of the data in the table portray, the existing classroom practices are mostly teacher-centred - the fact propped by the $65 \%$ responses falling on the point "very often". Furthermore, teacher-student interaction mostly taking place between the teacher and the brighter students resulting in the brighter students becoming active but the weaker ones remaining passive, and the weaker students having a feeling that teachers mostly pay their attention to the brighter students undoubtedly characterize the classroom scenario that is teacher-centred and, therefore, counter to the very soul of the semester system. This clearly suggests the fact about how much we have transformed ourselves when we switched over to the semester system from the annual one. In addition, as the majority of the responses reveal, the students lack any opportunity to discuss with their teachers about the strengths and weaknesses of the answers they supply and the consequent scores awarded - students remaining unknown about why they obtain more or less, no justification at all. The only perennial reason might be that the ones who did well secured good marks whereas the ones who did not obtained poor marks. This is further propped by one of my respondents' assertion that "students do not get chance to interact with the teachers". Similarly, another respondent states that "the classrooms are mainly teacher-centred in our college where students' involvement is rare".

Table 1: Responses of Students

\begin{tabular}{clcccc}
\hline S.N. & \multicolumn{1}{c}{ Construct } & $\mathbf{1}$ & $\mathbf{2}$ & $\mathbf{3}$ & $\mathbf{4}$ \\
\hline 1. & Teacher-centredness & $51(65 \%)$ & $18(23 \%)$ & $02(3 \%)$ & $08(10 \%)$ \\
2. & $\begin{array}{l}\text { Teacher attention more on } \\
\text { brighter students }\end{array}$ & $48(61 \%)$ & $12(15 \%)$ & $05(6 \%)$ & $14(18 \%)$
\end{tabular}


3. Teacher-student interaction

3. mostly with brighter students Tests only formal ones

4. as specified in respective courses of study

5. Students informed of marking criteria

Opportunities for discussing

6. the obtained scores with teachers.

Teachers seeking to maintain

7. classroom discipline with

$40 \%$ scores allocated to internal evaluation.

Weaker students remaining

8. passive but brighter ones active

9. Students tending to escape teacher tasks

10. Students doing work only for formality

Students doing teacher tasks

11. out of motivation for learning

12. Learning more meaningful

2. than undeserving scores

13. Student focus on scores rather that learning

14. Involvement of students in

4. malpractices for better marks

15. Respondent's personal involvement in malpractice

Requirement for $80 \%$

16. attendance met by the respondent.

\begin{tabular}{|c|c|c|c|}
\hline $55(70 \%)$ & $13(16 \%)$ & $02(3 \%)$ & $09(11 \%)$ \\
\hline $68(86 \%)$ & $11(14 \%)$ & $00(0 \%)$ & $00(0 \%)$ \\
\hline $55(70 \%)$ & $15(19 \%)$ & $02(3 \%)$ & $07(9 \%)$ \\
\hline $04(5 \%)$ & $16(20 \%)$ & $03(4 \%)$ & $56(71 \%)$ \\
\hline $42(53 \%)$ & $21(27 \%)$ & $05(6 \%)$ & $11(14 \%)$ \\
\hline $50(63 \%)$ & $13(16 \%)$ & $00(0 \%)$ & $16(20 \%)$ \\
\hline $29(37 \%)$ & $38(48 \%)$ & $09(11 \%)$ & $03(4 \%)$ \\
\hline $31(39 \%)$ & $33(42 \%)$ & $06(8 \%)$ & $09(11 \%)$ \\
\hline $41(52 \%)$ & $21(27 \%)$ & $03(4 \%)$ & $14(18 \%)$ \\
\hline $33(42 \%)$ & $42(53 \%)$ & $01(1 \%)$ & $03(4 \%)$ \\
\hline $52(66 \%)$ & $23(29 \%)$ & $04(5 \%)$ & $00(0 \%)$ \\
\hline $62(78 \%)$ & $05(6 \%)$ & $12(15 \%)$ & $00(0 \%)$ \\
\hline $31(39 \%)$ & $35(44 \%)$ & $02(3 \%)$ & $11(14 \%)$ \\
\hline $64(81 \%)$ & $11(14 \%)$ & $02(3 \%)$ & $02(3 \%)$ \\
\hline
\end{tabular}

\section{Notes:}

- 1: Very often 2: Sometimes 3: Rarely 4: Never

- In order to avoid clumsiness, the fractions in case of percentage have been avoided. Five hundredths or more have been counted as upper whole numbers whereas numbers below that have been ignored. Because of this, the totals of the percentiles across the table lack exactness in some cases. 
Teachers being limited within the formal tests, as the majority of the data reveal, again clearly indicates the answer to the question "How far have we transformed ourselves in the semester system?". Furthermore, the fact that a majority of the respondents feel the teachers' tendency to maintain discipline in the classroom on the ground that they possess the right to award the $40 \%$ of the scores - suggesting a sort of apprehension on the part of the students and, therefore, their obligation to remain silent even though they feel like pointing out any anomalies, be they felt or observed. The issues just mentioned definitely cross the horizons of annual-vs-semester discourse and lead to the broader reflections on the paradigms of instruction and assessment advocated elsewhere for the $21^{\text {st }}$ century - learner-centredness, learner autonomy, and the like. Nonetheless, it is interesting to note that none of the three teachers during the informal discussion confessed that their classrooms were teacher-centred.

As to the role of students also, the data portray a similar picture. Weaker students mostly remaining passive, students' tendency either to escape the assigned work or to complete the work only for formality sake, and students' focus on scores rather than on learning evidently suggest that students need to work much further to transform themselves in line with the spirit of the semester system. However, the data associated with the statements 10 and 11 in the table reveal a slightly contradictory fact. Moreover, the majority of the data show that the students themselves confess that generally they are involved in the malpractices of different sorts in order to obtain better grades. One interesting point depicted in the table is that a good majority of the respondents confess as a general phenomenon that students are involved in examination malpractices (Construct 14 in the table). But, at the same time, when they come to indicating their own personal involvement in malpractices for raising their scores, they seem to hesitate (Construct 15 in the table). In the same way, regarding the attendance of students, TU Semester System Operational Guideline (2014) provisions that:

Students failing to maintain 80 percent presence are not allowed to appear in the semester-end examinations and regarded as "not qualified". However, in case of serious illness the students with 70 percent attendance will be given chance to appear in the semester exam. (p. 3)

Now, as the data reveal, only $81 \%$ students "very often" meet the attendance requirement, which means that there are several students "not qualified" for the semester-end examinations. But the question is often raised about whether the concerned authorities at various levels can in general sustain the external pressures from different quarters and enforce the provision.

The disapproving comportment of students is further underscored by the students themselves thus: 
In my experience of test-taking, many students try to escape tests and assignments, and they just want to get through the formality set forth in the courses of study.

As the assignments used to be thick, teachers wouldn't check the papers line by line, which might not be possible. It is one of the reasons that weak students cheat from the talented ones and poor students get better marks whereas good students get poorer marks.

In a similar vein are the opinions of the teachers expressed during informal discussions. For instance one the three teachers in a rather complaining tone remarked that:

Our students haven't understood what they should do in the semester system. They act as if they were in the annual system classroom and fully depend on teachers. The teachers are helpless and they should do everything that they don't think is appropriate to do.

The teacher's opinions can, however, be considered suggestive of a number of connotations such as their own motivation and roles discussed earlier, the nonacademic pressures that compel them to act the way they do, an attempt to mask the general tendency of teachers characterizing their weaknesses, and the like.

\section{Conclusion}

The issue of "transformation" probed into in this paper emerged out of the comments and denigrations encountered not only during the personal communication with different stakeholders, particularly students and teachers in this specific context, but also in the public discourse - the comments and criticisms usually being directed towards others than oneself, towards the stakeholder groups other than the one's own. The tendency that lacks self-reflection and one's own transformation first gives rise to the big question "How much have we transformed ourselves?". This question of "transformation" undoubtedly applies to all the stakeholders concerned. Nonetheless, in this paper the emphasis has been on students and teachers and, as manifest in the data, it is not much hard to conclude that the stakeholders under consideration have remained largely untransformed even though the system in which they are functioning requires a drastic transformation in them. This study also underscores the significance of the rather aphoristic assertion "Let's begin the transformation from ourselves!'.

\section{References}

Anzene, S. J. (2014). Trends in Examination Malpractice in Nigerian Educational System and its Effects on the Socio-Economic and Political Development of Nigeria. Asian Journal of Humanities and Social Sciences (AJHSS), 2(3), 1-8. 
Aslam, H. D., Younis, A., Sheik, A. A., Maher, M., \& Abbasi, Z. A. (2012). Analyzing factors affecting students' satisfaction regarding semester system in universities of Pakistan. Journal of American Science, 8(10), 163-170.

Black, P. \& Wiliam, D. (1998). Inside the black box: Raising standards through class room assessment. Phi Delta Kappa, October, 1998, 1-13. Retrieved from https://www.rdc.udel.edu/wp-content/uploads/2015/04/InsideBlackBox.pdf

Duvie, A. N. \& Eluwa, B. O. (2016). Assessment of the effectiveness of management strategies for curbing examination malpractices in secondary schools in Nigeria. European JournalofEducation Studies, 2(11), 47-70. doi:10.5281/zenodo. 170920

O, A. O., \& Bankole, O. (2015). Reducing examination malpractices in Nigerian schools through effective continuous assessment (C.A) techniques as an alternative to one- shot examination in Osun state, Nigeria. American Journal of Educational Research, 3(6), 783-789. doi: 10.12691/education-3-6-18.

Pabla, M. S. (2014). A paradigm shift from semester system to annual system. Paripex - Indian Journal of Research, 3(4), 173-174.

Pathak, T. \& Rahman, M. A. (2013). Perception of students and teachers towards semester system: A study in some selected degree colleges of Nagaon town of Nagaon district of Assam. Journal of Education and Practice, 4(1), pp. 84-91.

Richards, J. C. \& Rodgers, T. S. (2002). Approaches and methods in language teaching. Cambridge: Cambridge University Press.

Shoukat, L. \& Muhammad, W. (2015). Perception of teachers and students towards the functionality of semester system at university level in the context of Pakistani social and administrative set-ups. International Journal of Teaching and Education, 3(4), pp. 68-80. doi: 10.20472/TE.2015.3.4.006

Singh, V. K. \& Kumar, P. (2016). Challenges in implementation of semester system in globalized world. International Journal of Applied Research, 2(3), pp. 89-91. Retrieved from www.allresearchjournal.com

TU (2014). TU semester system operational guideline. Unpublished guideline, TU, Kathmandu.

Yousaf, A. \& Hashim, M. (2012). A case study of annual and semester systems of examination on government college of management sciences, Peshawar, Pakistan. International Journal of Academic Research in Business and Social Sciences, 2(9), pp. 53-73. Retrieved from www.hrmars.com 